\title{
Oncogene amplification as tumor marker in a group of Colombian lung cancer patients*
}

\author{
Edward F. Carrillo, PhD ${ }^{1}$, Yazmín R. Arias, MSc ${ }^{1}$, Sandra J. Perdomo, PhD (c) ${ }^{1}$ \\ Fabio A. Aristizábal, PhD ${ }^{1}$, Paulina Ojeda, MD ${ }^{2}$, Diana M. Palacios, MD 3
}

\section{SUMMARY}

Introduction: In spite of recent treatment advances, lung cancer continues to be the first world cancer related death cause; its mortality associated occupied the fifth place in Colombia in 2004. Complete surgical resection is the therapeutic option with the greatest cure probability, however it results frequently ineffective given the current incapacity in Colombia to an early detection of the disease. This study reports the characterization of a group of 30 lung cancer patients regarding the gene dose (gene copy number) found at the loci corresponding to genes EGFR (erb B1), PIK3CA and C-myc in tumor samples, and compares the results with the dose found in adjacent lung from the same patients.

Methods: The gene dose of EGFR (erbB1), PIK3CA, and C-myc were measured by real time PCR in matched tumor and normal lung tissue samples. Results are expressed as the multiplicity of each gene dose with respect to a single copy reference gene. In this case the gene $H H B$ (human hemoglobin). Antiquity of the cases ranged from 5 to 10 years.

Results: An increased gene dose for EGFR and PIK3CA was a feature clearly associated to the tumor phenotype of the sample (found in 96 and $100 \%$ of the tumors respectively). Quantitative measure of this feature demonstrated for both genes a high sensitivity and specificity for tumor/normal discrimination as confirmed by the ROC analysis. On the other hand, the Spearman test showed a great correlation between EGFR and PIK3CA doses $(\rho=0.75)$. C-myc was the gene whose dose was less consistently correlated to the tumor phenotype, however most of the patients with amplified C-myc presented distant spread of tumor cells (metastasis) at diagnosis.

Conclusion: Quantitative measurement of EGFR, PIK3CA, and C-myc gene dose by real time PCR provides a method for tumor phenotype recognition in DNA samples from lung tissue. These markers can be considered at the construction of a marker panel for lung cancer detection on alternative, non-invasive clinical samples. However clinical value will depend on the use of additional molecular markers, some of which could be of epigenetic character.

Keywords: Lung cancer; Gene dose; Oncogenes; Real time PCR; EGFR; PIK3CA; C-myc

\section{Amplificación oncogénica como marcador tumoral en un grupo de pacientes con cáncer pulmonar}

\section{RESUMEN}

Introducción: A pesar de los avances terapéuticos actuales, el cáncer de pulmón sigue como la primera causa de muerte por cáncer en el mundo, ocupando Colombia el quinto lugar en mortalidad por este tipo de afección en el 2004. La resección quirúrgica total es la alternativa terapéutica con mayores probabilidades de curaciones, pero resulta poco efectiva en el país por la incapacidad actual para detectar tempranamente la enfermedad. Este trabajo informa la caracterización de un grupo de 30 pacientes con cáncer de pulmón con referencia a la dosis génica hallada en los loci correspondientes a los genes EGFR (erb B1), PIK3CA y C-myc en muestras tumorales, comparada con la dosis encontrada en el tejido normal adyacente de los mismos enfermos.

* Funds to support this research were provided by the División de Investigaciones, Universidad Nacional de Colombia, Bogotá, DC, Colombia(DIB).

1. Universidad Nacional de Colombia, Facultad de Ciencias, Departamento de Farmacia, Bogotá, DC, Colombia. e-mail: efcarrillob@unal.edu.co yrariasm@unal.edu.co sperdomo@javeriana.edu.com faaristizabalg@unal.edu.co

2. Hospital Santa Clara ESE, Departamento de Patología, Bogotá, DC, Colombia. e-mail: ojedapaulina@yahoo.com

3. Fundación Santa Fe de Bogotá (FSFB), Departamento de Patología, Bogotá, DC, Colombia. e-mail:diana.palacios@fsfb.org.co Received for publication April 23, 2008 Accepted for publication April 14, 2009 
Métodos: La dosis génica se midió en cada caso por PCR en tiempo real sobre ADN aislado de tejido tumoral y normal preservado en parafina de cada paciente. Los resultados se expresan como el número de veces que la dosis de cada gen sobrepasa la dosis de un gen de referencia, en este caso el $H H B$ (hemoglobina humana $\beta$ ). El rango de antigüedad de los casos fue de 5 a 10 años.

Resultados: Una dosis génica incrementada para los genes EGFR, PIK3CA demostró ser una característica claramente asociada con el fenotipo tumoral (96\% y 100\% de los tumores respectivamente). La medición cuantitativa de dicho fenómeno demostró en ambos casos gran sensibilidad y especificidad para la discriminación tumor/normal como lo confirma el análisis ROC. Por otro lado, la amplificación simultánea de ambos genes en el mismo paciente fue un hecho observado con alta frecuencia (Spearman $=0.75)$. La dosis de C-myc mostró una asociación menos consistente con el carácter tumoral, sin embargo todos los pacientes con $C$-myc amplificado presentaron dispersión distante de células tumorales (metástasis).

Conclusión: La detección cuantitativa del estado de amplificación de los genes EGFR, PIK3CA y C-myc por PCR en tiempo real provee un medio sensible para reconocer el fenotipo tumoral en muestras de ADN extraído de tejido pulmonar. Estos marcadores podrían considerarse en el desarrollo de sistemas de detección (paneles) orientados a muestras clínicas alternativas como el plasma sanguíneo. Sin embargo, la definición de un panel de marcadores con valor clínico requiere el estudio de marcadores adicionales entre los cuales podrían incluirse algunos de tipo epigenético.

Palabras clave: Cáncer de pulmón; Dosis génica; Oncogenes; PCR en tiempo real; EGFR; PIK3CA; C-myc.

Lung cancer is the first cancer related death cause worldwide, with and still increasing incidence ${ }^{1}$. Although other cancers are diagnosed at higher rates in Colombian population, as normally occurs in developing countries, it is considered a public health priority since life expectation when diagnosed continues to be very limited (around 10\%), and current diagnosis and treatment strategies have not produced the expected impact on these rates. In year 2000, lung cancer was third among neoplastic diseases in men ( 2493 cases) while in women it was sixth (1509 cases $)^{1}$. Diverse genetic and epigenetic alterations affect cell genome during carcinogenesis. Gene amplification, understood as gene copy number increase at specific genomic regions, has been normally observed during the adaptative response to physiological stress as one of the mechanisms by which synthesis of certain gene products is favored at quantities exceeding transcriptional capacity of just one copy ${ }^{2}$. Gene amplification is part of the normal development program of many organisms, however in mammals it is observed as a response to some cytotoxic agents or as a tumor development associated phenomenon ${ }^{3}$.

Gene copy number is a feature that can be easily evaluated in tumor isolatedDNA with common molecular techniques; suggesting a great potential as neoplastic marker. A conveniently selected panel of these markers could be used to detect and recognize the tumor phenotype both in high risk people given their exposure to known risk factors and in people who are suspected to have the disease although at an early stage non easily detectable by TAC or radiography. In addition, given the high correlation between epigenetic and genetic alterations occurring in lung tumor cells and those detectable in circulating cell free DNA from patients ${ }^{4}$, this approach could be applied on clinical samples whose obtainment is less invasive than biopsies like plasma or sputum $^{5}$. With this in mind, identification of molecular markers demonstrating high sensitivity and specificity for tumor phenotype recognition, easily testable by routine lab assays, is an important step for the construction of valuable diagnostic tools.

The present study characterized a group of lung cancer patients at various clinical stages, based on paraffin preserved tissue samples from lung cancer patients. Markers selected for the study were genes EGFR, PIK3CA, and C-myc, three components of the EGFR-PIK3CA-AKT signaling pathway. This pathway is known since its deregulation in tumor cells, which generally implies an increase of signal transmission, leads to the adoption of a pro-apoptotic signals non responsive phenotype ${ }^{6}$.

\section{MATERIALS AND METHODS}

Population and inclusion criteria. This paper reports the characterization of a group of patients with primary lung cancer regarding the gene dose at loci corresponding to EGFR, PIK3CA and C-myc genes in tumor cells, compared with those found in adjacent lung tissue with normal phenotype from the same patients. This is a descriptive cross-sectional study analyzing a 30 cases sample including patients with any of the following 
histological lung cancer subtypes: Squamous carcinoma (SQ), adenocarcinoma (AC), large cell carcinoma (LCC), and small cell carcinoma (SCC) (Table 1). Cases were provided by the Pathology Departments of Hospital Santa Clara ESE (Bogotá) and the Fundación Santafé de Bogotá (FSFB). Both materials and patients information were handled according to the scientific committees of the institutions. Paraffin blocks containing representative amounts of tumor or normal tissue from each patient were selected and tissues were microdissected and processed separately. Patient age ranged between 39 and 79 years at diagnosis, however segment from 65 to 74 years included most of them (Table 1).

DNA isolation from paraffin embedded tissue. Three sequential sections were obtained from every paraffin block. First was $3 \mu \mathrm{m}$ thick, CritiSolve deparaffinized (Fisher Scientific, Waltham MA. USA), H\&E stained and used to delimit suitable tissue areas. Remaining cuts were $10 \mu \mathrm{m}$, equally treated and used to collect tumor and normal lung from corresponding areas for processing.

Tissues collected from sections 2 and 3 were incubated in $100 \mathrm{mM}$ Tris- $\mathrm{HCl}$ (pH 7.2), $10 \mathrm{mM}$ EDTA, $55 \mu \mathrm{g} / \mathrm{ml}$ yeast tRNA, and $2.2 \mu \mathrm{g} / \mu \mathrm{l}$ Proteinase $\mathrm{K}$ (FERMENTAS, Glen Burnie, MD, USA) during $16 \mathrm{~h}$. Then the enzyme was heated and inactivated for $10 \mathrm{~min}$ at $100^{\circ} \mathrm{C}$. DNA was recovered by standard phenolchloroform extraction and ethanol precipitation. DNA amount was quantified by real time PCR using control commercial human DNA as amplification reference (PROMEGA, Madison WI, USA) and an Alu PCR target sequence ${ }^{7}$. Primers and amplification conditions were as previously presented by Weisenberger, et al., for amplicon named Alu-C4 ${ }^{8}$.

Measurement of gene copy numbers. Gene copy number measurement was performed through the relative comparison with the dose of a reference gene. The gene chosen as reference in this study was the gene coding for human hemoglobin beta chain $(H H B)$. Measurement of both reference and target genes was performed by real time PCR with the SyberGreen technology in a LightCycler ${ }^{\circledR} 2.0$ equipment, using the LightCycler ${ }^{\circledR}$ FastStart DNA Master SYBR Green I Kit (Cat. 12015099001) and the LightCycler ${ }^{\circledR}$ Control Kit DNA (Cat. 12158833001), all from ROCHE. The second Kit allowed the construction of a calibration curve for the reference gene linking the $\mathrm{CT}$ values generated by the equipment with known concentrations of template DNA. Then, all isolated DNA samples were subjected to real time PCR for the reference gen and the obtained CTs were interpolated in the standard curve.

The same technique was used to amplify genes EGFR, PIK3CA and C-myc, on every patient normal and tumor DNA isolates in addition to the control nontumor DNA from the kit, and the resulting CT values were compared with the matched CT values for HHB. The analysis was performed with the LightCycler 4.0 software (ROCHE) using the Relative Quantification Monocolor protocol. This analysis allowed to obtain gene dose for the target genes expressed as the number of times each gene dose exceeds that of the reference gene.

PCR conditions were as follows: $95^{\circ} \mathrm{C}-5 \mathrm{~min}$ for initial denaturation; followed by 45 cycles of $95^{\circ} \mathrm{C}-15$ seconds, $60^{\circ} \mathrm{C}-30$ seconds and $72^{\circ} \mathrm{C}-10$ seconds. Primer sequences both for the target genes and the reference gene are shown in Table 2. Every reaction was mounted in a final volume of $20 \mu \mathrm{l}$, primer concentration was always $1 \mu \mathrm{M}$ and remaining reagents were added according to manufacturer indications. Each run included positive and negative controls, reference gene calibrators and calibrators for the target gene.

Statistical analysis. Specificity and sensitivity of a gene dose increase as neoplastic marker can be expressed as the fraction of pathologically determined tumor tissues of the group where measured gene dose exceeds a given threshold. These are so considered «true positives» as determined by the molecular assay. Similarly, the «true negatives» are those samples whose detected amplification level is lower than the threshold and this feature coincides with a «normal» phenotype diagnosed by the pathologist. Since for the present study there are no available «thresholds» for each marker gene, a receiver operating characteristic analysis (ROC) was applied to the gene dose measurements. The ROC analysis allows locating a threshold so that the number of true positives and negatives is as high as possible.

ROC curves, graphs that illustrate the behavior of the specificity and sensitivity of phenotype recognition as the threshold moves along the range, where used observe the capacity of each marker to discriminate DNA isolates obtained from tumor and normal tissues. Two kind of analysis were performed: The first included tumor and normal tissues from the whole group of cases, 
Table 1

Patient characteristics and gene dose found

\begin{tabular}{|c|c|c|c|c|c|c|c|c|c|}
\hline \multirow[t]{2}{*}{ Case code } & \multirow[t]{2}{*}{ Gen } & \multirow[t]{2}{*}{ Age } & \multirow[t]{2}{*}{ Met $^{\mathrm{a}}$} & \multicolumn{2}{|c|}{$E G F R^{b}$} & \multicolumn{2}{|c|}{$P I K 3 C A^{\mathrm{b}}$} & \multicolumn{2}{|c|}{$C-m y c^{b}$} \\
\hline & & & & Tumor & Normal & Tumor & Normal & Tumor & Normal \\
\hline \multicolumn{10}{|c|}{ Adenocarcinomas } \\
\hline $1 \mathrm{AT}$ & M & NA & - & 28.5 & 2.1 & 8.8 & 1.2 & 0,69 & 1.36 \\
\hline $13 \mathrm{AT}$ & $\mathrm{F}$ & 64 & + & 28.02 & NA & 5.25 & 1.34 & 10.01 & 2.65 \\
\hline $11 \mathrm{AT}$ & $\mathrm{F}$ & 27 & + & 2.05 & 3.29 & NA & NA & 4.02 & 0.83 \\
\hline 129 AT & $\mathrm{F}$ & 67 & - & 28.0 & 1.18 & 9.5 & 1.04 & 2.33 & 2.61 \\
\hline $47 \mathrm{AT}$ & $M$ & 39 & NA & NA & NA & 4.02 & 1.36 & 9.98 & 1.57 \\
\hline $25 \mathrm{AT}$ & $\mathrm{F}$ & 70 & + & 16.01 & 2.1 & 8.7 & NA & 8.62 & 1.22 \\
\hline $34 \mathrm{AT}$ & $\mathrm{F}$ & 75 & - & 87.69 & 1.95 & 3.71 & 1.18 & 4.32 & 0.18 \\
\hline $4 \mathrm{AT}$ & $\mathrm{F}$ & 63 & - & NA & 2.46 & 5.45 & 0.9 & 2.83 & 1.56 \\
\hline $42 \mathrm{AT}$ & $\mathrm{F}$ & 63 & + & 11.35 & 1.95 & 3.89 & 1.45 & 14.33 & 1.82 \\
\hline $56 \mathrm{AT}$ & $M$ & 47 & + & 7.96 & 0.39 & NA & NA & 16.99 & 0.68 \\
\hline $81 \mathrm{AT}$ & $\mathrm{F}$ & 72 & + & 25.76 & 1.75 & 7.23 & 1.98 & 14.53 & 1.28 \\
\hline $92 \mathrm{AT}$ & $M$ & 39 & - & 16.01 & 1.2 & $\mathrm{NA}$ & 1.25 & 8.62 & NA \\
\hline $122 \mathrm{AT}$ & $\mathrm{F}$ & 63 & - & 36.59 & 2.16 & 5.25 & 0.86 & 1.22 & 3.44 \\
\hline $120 \mathrm{AT}$ & $M$ & 62 & + & NA & NA & 4.02 & 1.13 & 1.37 & 2.67 \\
\hline $2 \mathrm{AT}$ & $\mathrm{F}$ & 78 & - & 25.37 & 2.92 & 3.48 & 1.23 & 9.84 & 1.11 \\
\hline $96 \mathrm{AT}$ & $M$ & 64 & - & 37.79 & 2.46 & 5.75 & 4.02 & 0.39 & 0.1 \\
\hline
\end{tabular}

Squamous carcinomas

\begin{tabular}{|c|c|c|c|c|c|c|c|c|c|}
\hline 108 QT & $F$ & 64 & + & 16.2 & 3.19 & 2.08 & NA & 2.46 & 1.82 \\
\hline $45 \mathrm{QT}$ & $\mathrm{M}$ & 69 & - & 42.06 & NA & 5.24 & 1.87 & 1,38 & 0.72 \\
\hline 15 QT & $\mathrm{M}$ & 79 & + & 45.52 & 1.95 & 58.4 & NA & 64.95 & 0.87 \\
\hline $48 \mathrm{QT}$ & $\mathrm{M}$ & 70 & - & 35.09 & NA & NA & 5.22 & NA & NA \\
\hline $123 \mathrm{QT}$ & M & 73 & - & 60.22 & 1.12 & 5.18 & 1.15 & 1.76 & 3.65 \\
\hline 57 QT & M & 50 & - & 90.95 & 1.68 & NA & 1.25 & 1.32 & 1.56 \\
\hline 67 QT & M & 47 & - & 23.63 & 1.26 & NA & $\mathrm{NA}$ & 0.86 & 1.13 \\
\hline $82 \mathrm{QT}$ & M & 56 & NA & 62.32 & 0.38 & NA & $\mathrm{NA}$ & 1.18 & 0.98 \\
\hline $98 \mathrm{QT}$ & $\mathrm{F}$ & 39 & NA & 25.7 & NA & 5.03 & 1.21 & 1.82 & 1.51 \\
\hline
\end{tabular}

Large cell

65 LT (64)

76 LT (11)

$\begin{array}{ll}\text { NA } & \text { NA } \\ M & 46\end{array}$

$\begin{array}{ll}\mathbf{3 0 . 2 9} & 0.81 \\ \mathbf{8 2 . 2 8} & \text { NA }\end{array}$

$\begin{array}{llll}\text { NA } & 1.19 & \mathbf{9 7 . 5} & 1.67 \\ \mathbf{9 . 5} & 0.92 & \mathbf{1 0 5} & 1.76\end{array}$

Small cell lung cancer

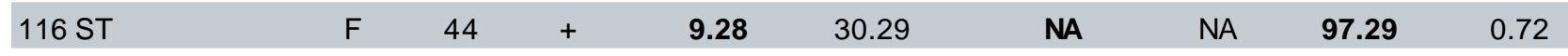

\section{Carcinoid}

118 CT F $\quad 42$ 86.16 NA 11.31 1.2 
Table 2

Primers for the genes evaluated

\begin{tabular}{lll}
\hline Gene & & \multicolumn{1}{c}{ Sequence } \\
\hline C-myc & Sense & 5'-CTCGGAAGGACTATCCTGCTGCCAA-3' \\
& Antisense & 5'-GGCGCTCCAAGACGTTGTGTGTTCG-3' \\
EGFR & Sense & 5'GAATTCGGATGCAGAGCTTC-3' \\
& Antisense & 5'GACATGCTGCGGTGTTTTC-3' \\
PIK3CA & Sense & 5'-AAATGAAAGCTCACTCTGGATTCC-3' \\
& Antisense & 5'-TGTGCAATTCCTATGCAATCG-3' \\
HHB & Sense & 5'-AGCAACCTCACAAACAGACACC-3' \\
& Antisense & 5'-CTACACATGCCCAGTTTC-3' \\
\hline
\end{tabular}

the second only included cases was carried out on the cases diagnosed as SQ or $\mathrm{AC}$, the most frequent subtypes among the group. This tool can be also used to assess the sensitivity and specificity of a marker to discriminate tumors with different histological subtypes. A marker with a «perfect» discriminatory power (sensitivity and specificity of $100 \%$ ) generates a ROC curve crossing the upper left corner of the graph, so that the area under the curve (AUC) matches $100 \%$ of the unit. An AUC equal or slightly higher than $50 \%(0.5)$ indicates a very low sensitivity and specificity of the assay ${ }^{9}$.

Gene dose results for each marker were also correlated as function of the phenotype by means of the Wilcoxon signed rank test. The utilization of a nonparametric test is necessary given the high frequency on zero values among the data (no gene dose increase) that does not allows to meet the requirement of the data to be «normally distributed». p values lower than 0.01 were considered significant.

Finally, a Spearman analysis was used to find any correlation of the gene dose with the age of the patients. A correlation coefficient $(\rho)$ close to the lower or upper limits of the range $(1 \geq \rho \geq 1)$ indicates a strong negative or positive correlation between the variables respectively. On the contrary, a ñ value close to zero (0) indicates that a significant correlation is not supported by the results. All the analysis described was performed with the software JMP 7.0 (SAS Institute).

\section{RESULTS}

This study reports the relative quantification of the genomic dose of EGFR, PIK3CA and C-myc in tumors and matched normal lung tissue from 30 lung cancer cases with diverse pathological diagnoses. Both the reference $H H B$ gene and the three target genes were Real Time PCR detected on both human control genomic DNA and isolates from tumor and normal tissues from each patient in order to obtain a relative quantification of the genomic dose increase. The estimation was finally achieved by interpolation in a standard curve.

Graphic 1 shows the gene dose values of genes EGFR, PIK3CA, and C-myc related to the dose of HHB. Gene $H H B$ is one of the most widely used reference genes, since its gene dose ( 2 copies, by human diploid genome) is rarely altered with neoplastic transformation ${ }^{10}$. In tumor samples the detected EGFR gene dose ranged from 2 to 90 times that of $H H B .60 \%$ of the cases located the 20-40 interval. On the contrary, not any of the normal matched tissues significantly differed from the reference value (Graphic 1, Panel A). The corresponding ROC graph shows a high capacity of this gene for tumor origin identification in DNA isolates, which is confirmed by an AOC value close to 1 . The Wilcoxon test yielded a $p<0,0001$ for the discrimination between tumor and normal samples.

PIK3CA demonstrated a similar behavior. It showed a good capacity for tumor/normal discrimination 
A
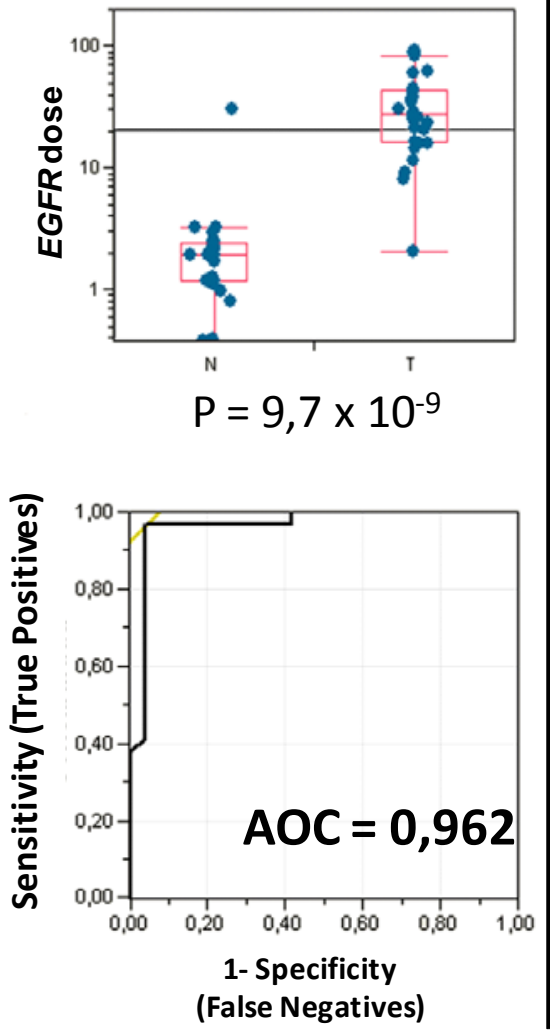

B
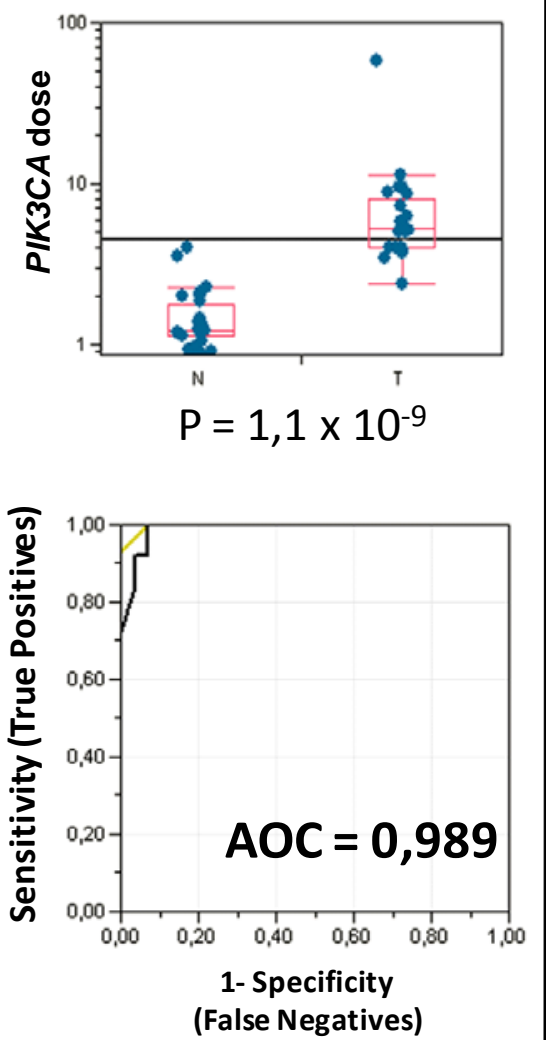

C
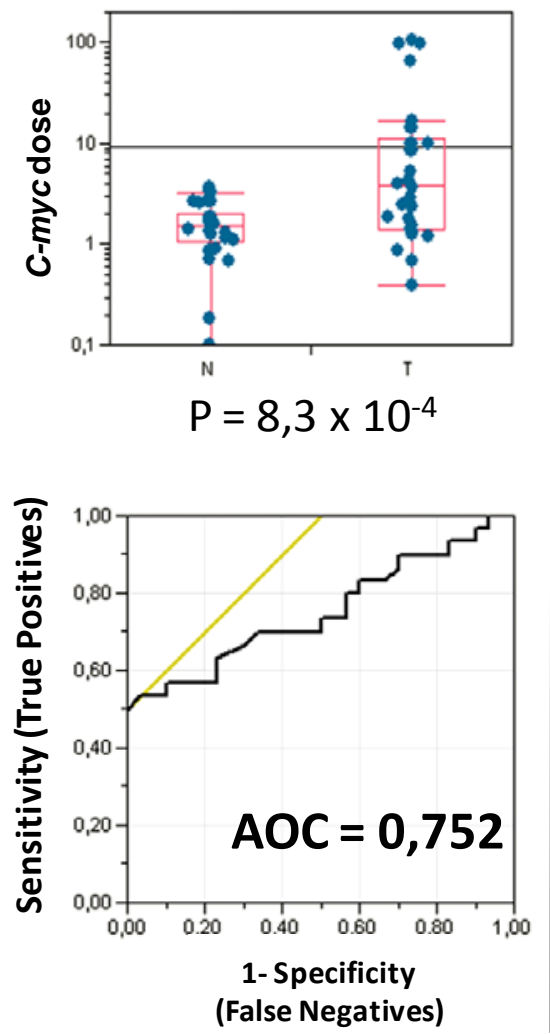

Graphic 1. Comparison of gene copy numbers of EGFR (panel A), PIK3CA (Panel B), and C-myc (Panel C) in tumor and normal lung samples. The $p$ values shown were obtained with the Wilcoxon signed rank test. The corresponding ROC curves, constructed considering the tumor character as the "positive value» are shown at the bottom of each panel. An AUC value close to 1 indicates great sensitivity and specificity of the marker at tumor/normal discrimination.

confirmed by the Wilcoxon p value obtained $(\mathrm{p}<0,0001)$. Although dose values locate within a narrower range than EGFR, the significance has a similar magnitude order (Graphic 1, Panel A). AUC in the ROC curve was higher than 0,9 indicating a good tumor/normal discrimination capacity (Graphic 1, Panel B).

Although the graph corresponding to oncogene $C$ myc indicates a similar behavior, the $p$ value obtained at the Wilcoxon test was 0,00083 (Graphic 1, Panel C). This $P$ value is 5 magnitude orders less significant than the values obtained for EGFR and PIK3CA. The AOC of the ROC graph is also lower indicating a low capacity of this gene as neoplasm marker.

The ROC analysis allows an estimation of the best threshold for discrimination between normal and tumor samples with each marker gene by maximizing the number of true positives and negatives. The best threshold gene doses, based on this group of patients, generated by this analysis for the three genes are presented in Table 3.

We wanted to evaluate marker performance when considering only DNA isolates from patients with the same lung cancer subtype. Graphic 2 presents the gene dose results for ADs and SQs separately. Graphic 2, Panels $\mathrm{A}$ and $\mathrm{B}$ shows the distribution of the gene dose of EGFR and PIK3CA. Both genes continue to be good markers of the two groups of tumors $(p<0,0001)$. However, the p value obtained at the assay with $C$-myc in ADs was 0,0033; indicating a lower significance of the assay. With SQs, the discrimination was null $(\mathrm{p}=0,8168)$.

Possible correlations between quantitative variables can be observed by means of the Spearman nonparametric test. Here, Spearman test was used to 
Table 3

Frequency of DNA isolates cases with gene dose higher than the corresponding ROC threshold

\begin{tabular}{lccc}
\hline \multirow{2}{*}{$\mathbf{n}=\mathbf{3 0}$} & ROC*Threshold & \multicolumn{2}{c}{ Origin (\%) } \\
\cline { 3 - 4 } & & Tumor & Normal tissue \\
\hline EGFR & 7.96 & $27(90.0)$ & $1(3.3)$ \\
PIK3CA & 2.36 & $28(93.0)$ & $2(6.6)$ \\
C-myc & 4.02 & $14(46.6)$ & $0(0.0)$ \\
\hline
\end{tabular}
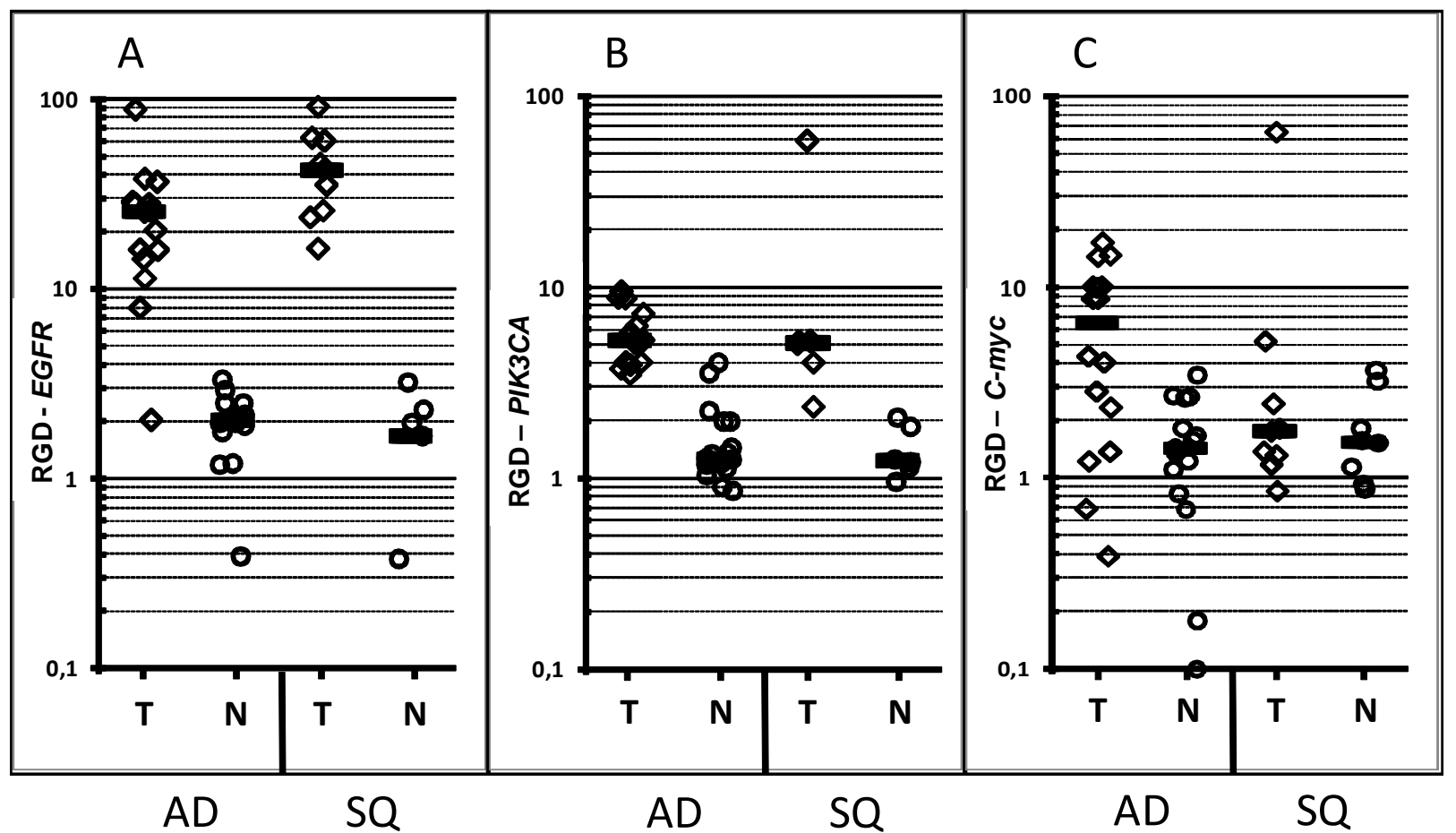

Graphic 2. Distribution of the gene dose parameter in ADs and SQ tumor and normal samples for EGFR, $P I K 3 C A$ and $C$-myc. The solid horizontal line indicates the median of each group. While tumor/normal discrimination is clear with EGFR and PIK3CA, discrimination power of C-myc is lower, mainly in SQs.

search for any influence of the age of the patients on the results. Calculation of the Spearman rho coefficient did not revealed any influence of this variable $(-0,5<\rho<0,5)$. However, a positive association between EGFR and PIK3CA gene doses was found $(\rho=0.75)$. It was a frequent characteristic among our cases to find these two genes at increased gene doses simultaneously. None of them showed such correlation with C-myc.

Although clinical information about the cases was fragmentary, given case antiquity, a common available data was the presence of metastasis. The presence of metastasis was a characteristic notably associated with an increase in the genomic dose of $C$-myc, that was not found with EGFR or PIK3CA. Nine out of twelve cases with positive amplification also had metastasis. Two of the three remaining cases were diagnosed as carcinoids (Table 1), which are known by their low metastasis rate. Both EGFR and PIK3CA were found with increased gene doses in the two carcinoids of this study. On the contrary, C-myc had a dose close to that of HHB in these cases.

There were also two cases diagnosed as large cell carcinoma (LCC) that demonstrated very high increases of dose for the three genes. The only SCC included 
demonstrated the highest $C$-myc dose of the group (Table 1). SCCs are very aggressive cancers with high metastasis rate, which is compatible with the general tendency found here. This particular case was metastatic to the pleura, pancreas, ovary, pericardium, and adrenal glands.

\section{DISCUSSION}

The three genes analyzed have important functions at regulation of cell responsiveness to external proapoptotic signals, as part of the PIK3CA/Akt signaling pathway. Several signaling proteins involved in this pathway with likely oncogenic potential, have been reported as amplified genes in cancer ${ }^{11-14}$. EGFR(ErbB1) belongs to the ErbB family which also includes Her2/ neu (ErbB2), ErbB3 and ErbB4. They usually localize to the membrane forming homo or heterodimers which have the epidermal growth factor receptor (EGF) as main ligand. Binding of the ligand induces the ATPase activity of the cytoplasmic domain, triggering signal transduction. PIK3CA after being activated by the membrane complex transfers a phosphate group to the phosphatidil inositol $(4,5)$-diphosphate producing a $(4,5$, 6) phosphorylated product which promotes AKT proteins recruiting to the sub membrane region. These events determine antiapoptotic signals to reach the nucleus continuously ${ }^{11}$. An increase in the function of these components contributes to cell cycle progression.

Several treatment strategies try to control the function of these components, mainly the receptors of EGF, EGFR and Her2/neu. Since drug efficiency frequently depends on an efficient interaction with the target molecule, cells with increased expression of the target are intrinsically more sensitive to drug action ${ }^{15}$. However, other features such as certain mutations or the gene dose have also an important influence ${ }^{16}$. Gene dose characterization is one of the possible tools to correctly classify the cases so that individualized treatment programs lead to higher response rates and longer survival ${ }^{17}$.

These results confirm EGFR dose measurement potential as tumor phenotype marker in DNA isolates from lung cancer patients. The ROC analysis for EGFR demonstrated great sensitivity and specificity as neoplasm marker. EGFR gene copy number is a parameter frequently considered to personalize the treatment because it is frequently determinant of the efficacy of some drugs used in chemotherapy ${ }^{18}$. According to our experience, in Colombian cases it is also frequent to find increases in EGFR gene dose; however, it is not defined yet if this property determines drug efficiency. Considering individual EGFR sequence mutations, as previously found ${ }^{19}$, or different types of markers such as methylated $\mathrm{CpG}$ islands in addition to gene dose variations could provide additional criteria to improve treatment success.

PIK3CA demonstrated a similar potential, according to its ROC curve. Copy number increase is a frequent event in ovarian cancer ${ }^{20}$. However, the study by Okudela et al. ${ }^{14}$, in lung cancer reported frequency of PIK3CA amplification among Japanese patients in only $18,3 \%$ of the cases. That study concluded that both the PIK3CA dose increase and the presence of certain mutations are events with oncogenic potential, but mutually exclusive ${ }^{14}$. In the present group of cases PIK3CA copy number was 93\% (Table 3). Different exposures to environmental factors are likely the explanation to observed differences between developed and non developed countries. This fact implies that genomic alteration associated to lung cancer development may significantly differ between different locations, so that molecular markers performing well in a given population could be useless in another population, justifying future studies seeking for a complete characterization of the genetic behavior associated to cancer advent under local conditions. Regarding C-myc, its copy number was found frequently increased in tumor samples from our patients; however, the ROCAUC demonstrated lower sensitivity and specificity.

In order to construct frequency tables discriminating samples with high and low gene copy numbers, the best threshold determined by the ROC analysis for each gene as cutoff was taken. The results are shown in Table 3. Calculation of these thresholds are based only on the present group of patients; if a more widely usable value is to be determined, it is necessary to do a similar analysis with an statistically really significant number of patients. Thresholds presented here are just reference values for those studies. However, the new thresholds that would be defined for Colombian population will become useful screening tools for detection in more accessible samples like blood or sputum.

ADs and SQ belong to a large category of lung 
cancers known as NSCLCs. Large cell lung carcinomas (LCLC) are also included in this category, but they are frequently considered as tumors which have lost their initial differentiation so that the original AD or SQ morphology is not easy recognizable. The two cases in our group of cases demonstrated very high dose increases for the genes evaluated (Table 1), suggesting that these kind of molecular alterations continue to increase as the neoplasm progresses. These makes sense in cancer development is observed as a micro-evolutive process where selection occurs so that cell lineages with more marked proliferative and survival features end up predominating among survivors ${ }^{21}$. To harbor oncogenes at increased copy numbers is a characteristic that is conserved as the neoplasm evolves.

Our study revealed a significant co-variation between EGFR and PIK3CA gene doses not only by coincidence of the amplified state but, within each gene range, the magnitude of the phenomenon. This supports the idea that the components of a signaling pathway should be similarly affected for a real modification of the strength of the signal to occur. This observation has been previously made for the PIK3CA/Akt signaling pathway ${ }^{22}$. It is necessary to perform similar research on other components of the pathway like the AKT proteins and protein kinase $\mathrm{B}$ (PKB), in order to find other possible markers for cancer detection. The analysis of $\mathrm{PKB}$ function in NSCLC has already been found to correlate with PIK3CA gene dose ${ }^{22}$.

Even though our evidence is not conclusive, behavior of C-myc in NSCLCs was found to be associated with the presence of metastasis. This hypothesis must be more clearly demonstrated in future studies. Identification of molecular markers clearly associated with clinical features of patients is a promising research line that will eventually lead to achieve a close monitoring of cases and will provide additional tools for personalized treatment.

Development of a reliable tool for cancer detection based on molecular alterations will require evaluating a large number of candidate genes and the definition of an adequate panel of markers that could include epigenetic markers like methylated genes.

\section{ACKNOWLEDGEMENTS}

This research was supported by the División de
Investigaciones of the Universidad Nacional de Colombia (DIB-UNAL). We also thank to the Institute of Genetics and the Instituto de Biotecnología belonging to this University.

\section{REFERENCES}

1. Parkin DM, Bray F, Ferlay J, Pisani P. Estimating the world cancer burden: GLOBOCAN 2000. Int J Cancer. 2001; 94: 153-6.

2. Schwab M. Oncogene amplification in solid tumors. Semin Cancer Biol. 1999; 9: 319-25.

3. Alitalo K. Amplification of cellular oncogenes in cancer cells. Med Biol. 1984; 62: 304-17.

4. Fleischhacker M, Schmidt B. Circulating nucleic acids (CNAS) and cancer. A survey. Biochim Biophys Acta . 2007; 1775: 181232.

5. Wang YC, Hsu HS, Chen TP, Chen JT. Molecular diagnostic markers for lung cancer in sputum and plasma. Ann NYAcad Sci. 2006; 1075: 179-84.

6. Osaki M, Oshimura M, Ito H. PI3K-AKT pathway: its functions and alterations in human cancer. Apoptosis. 2004; 9: 667-76.

7. Walker JA, Kilroy GE, Xing J, Shewale J, Sinha Sk, Batzer MA. Human DNA quantitation using alu element-based polymerase chain reaction. Anal Biochem. 2003; 315: 122-8.

8. Weisenberger Dj, Campan M, Long Ti, Kim M, Woods C, Fiala E, et al. Analysis of repetitive element DNA methylation by methylight. Nucleic Acids Res. 2005; 33: 6823-36.

9. Fawcett T. roc graphs: notes and practical considerations for researchers. HP Labs Tech Report. 2004; 38 pages. DOI: HPL2003-4. Corrected version 2004.

10. Millson A, Suli A, Hartung L, Kunitake S, Bennett A, Nordberg $\mathrm{MC}$, et al. Comparison of two quantitative polymerase chain reaction methods for detecting her $2 /$ neu amplification. $J \mathrm{Mol}$ Diagn. 2003; 5: 184-90.

11. Massion PP, Taflan PM, Shyr Y, Rahman SM, Yildiz P, Shakthour B, et al. Early involvement of the phosphatidylinositol 3-kinase/akt pathway in lung cancer progression. Am J Respir Crit Care Med. 2004; 170: 1088-94.

12. Mitani S, Kamata H, Fujiwara M, Aoki N, Tango T, Fukuchi $\mathrm{K}$, et al. Analysis of c-myc DNA amplification in non-small cell lung carcinoma in comparison with small cell lung carcinoma using polymerase chain reaction. Clin Exp Med. 2001; 1: 10511.

13. Moroni M, Veronese S, Benvenuti S, Marrapese G, SartoreBianchi A, Di Nicolantonio F, et al. Gene copy number for epidermal growth factor receptor $(E G F R)$ and clinical response to antiegfr treatment in colorectal cancer: a cohort study. Lancet Oncol. 2005; 6: 279-86.

14. Okudela K, Suzuki M, Kageyama S, Bunai T, Nagura K, Igarashi $\mathrm{H}$, et al. PIK3CA mutation and amplification in human lung cancer. Pathol Int. 2007; 57: 664-71.

15. Cappuzzo F, Varella-Garcia M, Shigematsu H, Domenichini I, Bartolini S, Ceresoli GL, et al. Increased her2 gene copy number 
is associated with response to gefitinib therapy in epidermal growth factor receptor-positive non-small-cell lung cancer patients. J Clin Oncol. 2005; 23: 5007-18.

16. Sasaki H, Kawano O, Endo K, Yukiue H, Yano M, Fujii Y. EGFRVIII mutation in lung cancer correlates with increased EGFR copy number. Oncol Rep. 2007; 17: 319-23.

17. Cappuzzo F. Predictive factors for response and for resistance to tyrosine kinase inhibitor therapy in lung cancer. $J$ Thorac Oncol. 2007; 2 (5 suppl): 12-4.

18. Sakurada A, Tsao MS. Predictive biomarkers for EGFR therapy. IDRUGS. 2009; 12: 34-8.

19. Takano T, Ohe Y, Sakamoto H, Tsuta K, Matsuno Y, Tateishi $\mathrm{U}$, et al. Epidermal growth factor receptor gene mutations and increased copy numbers predict gefitinib sensitivity in patients with recurrent non-small-cell lung cancer. J Clin Oncol. 2005; 23: 6829-37.

20. Shayesteh L, Lu Y, Kuo WL, Baldocchi R, Godfrey T, Collins $\mathrm{C}$, et al.PIK3CA is implicated as an oncogene in ovarian cancer. Nat Genet. 1999; 21: 99-102.

21. Cahill DP, Kinzler KW, Vogelstein B, Lengauer C. Genetic instability and darwinian selection in tumours. Trends Cell Biol. 1999; 9: M57-60.

22. Massion PP, Kuo WL, Stokoe D, Olshen AB, Treseler PA, Chin K, et al. Genomic copy number analysis of non-small cell lung cancer using array comparative genomic hybridization: implications of the phosphatidylinositol 3-kinase pathway. Cancer Res. 2002; 62: 3636-40. 